\title{
Epidemiological profile of healthcare-associated infections caused by Carbapenemase-producing Enterobacteriaceae*
}

\author{
Perfil epidemiológico das infecções relacionadas à assistência à saúde \\ causadas por Enterobactérias produtoras de Carbapenemase \\ Perfil epidemiológico de las infecciones relacionadas con la asistencia sanitaria \\ causadas por Enterobacterias productoras de Carbapenemasa
}

How to cite this article:

Alvim ALS, Couto BRGM, Gazzinelli A. Epidemiological profile of healthcare-associated infections caused by Carbapenemase-producing Enterobacteriaceae. Rev Esc Enferm USP. 2019;53:e03474. DOI: http://dx.doi.org/10.1590/S1980-220X2018001903474

\author{
André Luiz Silva Alvim ${ }^{1}$ \\ Bráulio Roberto Gonçalves \\ Marinho Couto ${ }^{2}$ \\ Andrea Gazzinelli ${ }^{1}$ \\ * Extracted from the dissertation: "Fatores de \\ risco para infecções relacionadas à assistência à \\ saúde causadas por Enterobactérias produtoras \\ de Carbapenemase portadoras do gene blaKPC", \\ Programa de Pós-Graduação em Enfermagem, \\ Universidade Federal de Minas Gerais, 2017. \\ ${ }^{1}$ Universidade Federal de Minas \\ Gerais, Programa de Pós-Graduação em \\ Enfermagem, Belo Horizonte, MG, Brazil. \\ ${ }^{2}$ Centro Universitário de Belo Horizonte - \\ UniBH, Departamento de Engenharia e \\ Estatística, Belo Horizonte, MG, Brazil.
}

\begin{abstract}
Objective: To study the epidemiological profile of Healthcare-associated Infections caused by Enterobacteria which carry the Klebsiella pneumoniae Carbapenemase gene (blaKPC) in the hospital environment. Method: A descriptive study was conducted in a private hospital in Belo Horizonte, MG, Brazil, which included all patients with infections caused by Enterobacteriaceae which carry the Klebsiella pneumoniae Carbapenemase gene. The data were collected by the Automated System of Hospital Infection Control and analyzed by descriptive statistics by the Epi Info 7 program. Results: Eighty-two (82) patients participated in the study. Klebsiella pneumoniae was the most frequent species $(68 \%)$ isolated in blood (30\%), bronchoalveolar lavage (22\%) and urine (18\%), while catheter-associated bloodstream infection (30\%) predominated regarding topography. A case fatality rate of $62 \%$ is highlighted in evaluating the outcome. Conclusion: The resistance genes spread rapidly, limiting the antimicrobial options for treating infectious diseases. The epidemiological profile of Healthcare-Associated Infections found in this study can be prevented by prevention and infection control programs.
\end{abstract}

\section{DESCRIPTORS}

Enterobacteriaceae; Cross Infection; Drug Resistance, Microbial; Infection Control. 


\section{INTRODUCTION}

"Healthcare-Associated Infections (HAIs) represent a serious global public health problem, as they lead to longer hospitalization, higher healthcare costs and increased morbidity and mortality in health services ${ }^{(1)}$. It is estimated that the incidence in Europe is 4 million inpatients per year. In the United States, approximately 1.7 million HAIs are reported annually, with records higher than 90,000 deaths. In Brazil, it is known that the last national study showed a HAI prevalence of $15 \%$ in hospitals"(1-3).

Antibiotics (ATB) have revolutionized the treatment of HAIs, representing a major breakthrough for modern medicine. However, the empirical, indiscriminate and irrational use of these substances has become an exponentially dangerous factor for the development of antimicrobial resistance ${ }^{(4-6)}$.

Carbapenemase-producing Enterobacteriaceae which carry the blaKPC gene (CPE-KPC) stand out among bacteria of epidemiological importance which present unrestrained growth in its resistance profile. These microorganisms spread rapidly and end up being associated with a high mortality rate by limiting the therapeutic options for infected patients ${ }^{(5,7-8)}$.

Although international studies are well advanced in relation to the subject, especially in those aspects which concern the rapid genotypic laboratory detection of the microorganism in the hospital environment, the World Health Organization (WHO) affirms that there are still gaps in research that should be better investigated. In addition, data in Brazil are limited in relation to the epidemiological aspects of the blaKPC gene among enterobacteria ${ }^{(8-11)}$.

It is believed that the data will serve as subsidies for broad discussions related to planning actions which reduce the chance of infection in Health Care Facilities. Therefore, this study aimed to raise the epidemiological profile of HAIs caused by Carbapenemase-producing Enterobacteriaceae which carry the blaKPC gene (CPE-KPC) in the hospital environment.

\section{METHOD}

\section{STUDY DESIGN}

This is an epidemiological and descriptive study.

\section{SCENARIO}

This study was conducted in a general private hospital of Belo Horizonte, MG, Brazil. The institution has 167 inpatient beds and 30 Intensive Care beds, with an average of 1,130 patients hospitalized per month and performs approximately 7,389 surgeries per year.

Notification of HAIs is performed through an active prospective search by the nurses of the Infection Control Service. In this case the National Healthcare Safety Network (NHSN) system of the Center for Disease Control and Prevention (CDC) is used with the support of a Hospital Infection Control software ${ }^{(12)}$. The NHSN methodology has been incorporated by the study hospital for HAI diagnosis since 2002, justifying the choice of the CDC criteria for HAI reporting.

\section{Study population}

The potential study population was comprised of 82 (100\%) patients who acquired HAI caused by CPE-KPC between 2013 and 2017. All patients diagnosed with the blaKPC gene had phenotypic confirmation by the hospital laboratory of this study and genotype by the Public Health Central Laboratory of Minas Gerais ${ }^{(13)}$.

\section{SeleCTION CRITERIA}

The inclusion criteria were being 18 years of age or older and having 3 days or more of hospital stay. According to the $\mathrm{CDC}$, an infection is considered HAI when the occurrence date occurs during the third day of admission or after this period $^{(12,14)}$.

The period delimitation (2013 to 2017) was due to the fact that the electronic medical record in the study hospital was totally installed in June/2012, in addition to having undergone a major structural reform in the three Intensive Care Units during the same period, which could have contributed to a change in the local microbiological profile.

\section{Data collection}

Data collection was performed between January and May 2017 by the researcher through a search in the Automated Hospital Infection Control System (SACIH - Sistema Automatizado de Controle de Infeç̧ão Hospitalar) and the patient's electronic medical record. SACIH was created and validated in 1993 by physicians, statisticians and system analysts using the adapted methodology of the National Nosocomial Infections Surveillance (NNIS) of the United States ${ }^{(2,12)}$.

The collection instrument was composed of sociodemographic data (age, gender, skin color, education and marital status) and epidemiological data (microorganism, specimen, HAI topography, minimal inhibitory concentration of antimicrobials which follow the standards of the Clinical \& Laboratory Standards Institute, and the patient outcome $)^{(14)}$.

\section{DATA ANALYSIS AND PROCESSING}

After compiling the information, the results were aggregated into a spreadsheet generated by Microsoft Excel $2013^{\circledR}$.

For processing the data, descriptive statistical analysis was performed by the Epi Info ${ }^{\circledR}$ version 7 program for presenting absolute values, percentages, $95 \%$ confidence intervals (CI 95\%), mean and standard deviation.

\section{ETHICAL ASPECTS}

The project was approved by the Research Ethics Committee under protocol number 1.887 .637 (2017) in compliance with Resolution 466/2012 of the National Health Council, which refers to the Guidelines and Norms Regulating Human Research ${ }^{(15)}$.

\section{RESULTS}

The study sample consisted of $82(100 \%)$ patients with a mean age of 71 years ( $s d \pm 13.6$ ), with a minimum age of 30 and a maximum of 93 years. The socio-demographic 
profile (Table 1) showed a prevalence of males (66\%), married $(57 \%)$, white $(66 \%)$ and high school graduates (49\%).

Table 1 - Sociodemographic profile of patients with HAls caused by Enterobacteria carrying the gene - Belo Horizonte, MG, Brazil, 2017.

\begin{tabular}{lccc}
\hline Variables & $\mathbf{n}$ & $\%$ & $\mathbf{C l 9 5} \%$ \\
\hline Gender & & & \\
Female & 28 & 34 & $25-39$ \\
Male & 54 & 66 & $61-75$ \\
\hline Civil status & & & \\
Married & 47 & 57 & $46-68$ \\
Separated/Others & 23 & 28 & $19-39$ \\
Single & 12 & 15 & $8-24$ \\
\hline Skin color & & & \\
White & 54 & 66 & $55-76$ \\
Black & 18 & 22 & $14-32$ \\
Brown & 10 & 12 & $6-21$ \\
\hline Education & & & \\
Elementary & 15 & 18 & $11-28$ \\
High school & 40 & 49 & $38-60$ \\
Undergraduate & 26 & 32 & $22-43$ \\
Postgraduate & 1 & 1 & $0-7$ \\
\hline Note (n-82) & & &
\end{tabular}

Note: $(n=82)$.

Most of the HAIs caused by CPEC-KPC occurred by Klebsiella pneumoniae (68\%) and were isolated in blood (30\%), bronchoalveolar lavage (22\%) and urine (18\%). In relation to topography, there was a prevalence of catheterassociated bloodstream infection (BSI) (30\%). In the outcome evaluation, a case fatality rate of $62 \%$ of the patients was highlighted (Table 2).
Table 2 - HAl profile caused by Enterobacteria carrying the blaKPC gene - Belo Horizonte, MG, Brazil, 2017.

\begin{tabular}{|c|c|c|c|}
\hline Variables & n & $\%$ & $\mathrm{Cl} 95 \%$ \\
\hline \multicolumn{4}{|l|}{ Bacteria } \\
\hline Klebsiella pneumoniae & 56 & 68 & $57-78$ \\
\hline Serratia marcescens & 19 & 23 & $15-34$ \\
\hline Enterobacter cloacae & 7 & 9 & $4-17$ \\
\hline \multicolumn{4}{|l|}{ Specimen } \\
\hline Blood & 25 & 30 & $21-42$ \\
\hline Bronchoalveolar lavage & 22 & 27 & $16-35$ \\
\hline Urine & 18 & 22 & $14-32$ \\
\hline Tissue fragment & 7 & 9 & $3-15$ \\
\hline Abdominal fluid & 7 & 9 & $3-15$ \\
\hline Catheter tip & 3 & 4 & $1-10$ \\
\hline \multicolumn{4}{|l|}{ Topography } \\
\hline Catheter-associated bloodstream infection & 25 & 30 & $21-42$ \\
\hline Catheter-associated urinary tract infection & 18 & 22 & $14-32$ \\
\hline $\begin{array}{l}\text { Infection of the lower respiratory tract, } \\
\text { except pneumonia }\end{array}$ & 16 & 20 & $12-30$ \\
\hline Surgical site infection & 14 & 17 & $10-27$ \\
\hline Ventilator-associated pneumonia & 6 & 7 & $3-15$ \\
\hline Cardiovascular system infection & 3 & 4 & $1-10$ \\
\hline \multicolumn{4}{|l|}{ Outcome } \\
\hline Discharge/Transfer & 31 & 38 & $27-49$ \\
\hline Death & 51 & 62 & $51-73$ \\
\hline
\end{tabular}

Note: $(n=82)$.

Microbial susceptibility profile to antimicrobials tested by Minimum Inhibitory Concentration (MIC) showed resistance to carbapenems meropenem, imipenem and ertapenem among Klebsiella pneumoniae, Serratia marcescens and Enterobacter cloacae (Table 3).

Table 3 - Descriptive analysis of the sensitivity profile between Carbapenemase-producing Enterobacteriaceae carrying the blaKPC gene - Belo Horizonte, MG, Brazil, 2017.

\begin{tabular}{|c|c|c|c|c|c|c|}
\hline \multirow[t]{2}{*}{ Antimicrobials } & \multicolumn{2}{|c|}{$\begin{array}{l}\text { Klebsiella pneumoniae* } \\
\qquad(\mathrm{n}=56)\end{array}$} & \multicolumn{2}{|c|}{$\begin{array}{l}\text { Serratia marcescens** } \\
\qquad(\mathrm{n}=19)\end{array}$} & \multicolumn{2}{|c|}{$\begin{array}{l}\text { Enterobacter cloacae } \\
\qquad(\mathrm{n}=7)\end{array}$} \\
\hline & $\mathbf{n}$ & $\%$ & $\mathbf{n}$ & $\%$ & $\mathbf{n}$ & $\%$ \\
\hline Nalidixic acid & 1 & 2 & 5 & 26 & 1 & 14 \\
\hline Amikacin & 44 & 79 & 5 & 26 & 3 & 43 \\
\hline Amoxicillin/Clavulanic acid & 1 & 2 & 2 & 11 & 2 & 29 \\
\hline Ampicillin & 2 & 4 & 2 & 11 & 1 & 14 \\
\hline Ampicillin/Sulbactam & 0 & 0 & 2 & 11 & 1 & 14 \\
\hline Cefepima & 6 & 11 & 1 & 5 & 0 & 0 \\
\hline Cefoxitin & 1 & 2 & 8 & 42 & 2 & 29 \\
\hline Ceftazidime & 0 & 0 & 1 & 5 & 0 & 0 \\
\hline Ceftriaxone & 1 & 2 & 0 & 0 & 0 & 0 \\
\hline Cefuroxime & 0 & 0 & 3 & 16 & 2 & 29 \\
\hline Cefuroxime axetil & 2 & 4 & 5 & 26 & 2 & 29 \\
\hline Ciprofloxacin & 19 & 34 & 14 & 74 & 5 & 71 \\
\hline Colistin & 47 & 84 & 1 & 5 & 7 & 100 \\
\hline Ertapenem & 0 & 0 & 0 & 0 & 0 & 0 \\
\hline Gentamicin & 29 & 52 & 15 & 79 & 5 & 71 \\
\hline Imipenem & 0 & 0 & 0 & 0 & 0 & 0 \\
\hline Meropenem & 0 & 0 & 0 & 0 & 0 & 0 \\
\hline Piperacillin/Tazobactam & 1 & 2 & 5 & 26 & 3 & 43 \\
\hline Tigecycline & 30 & 54 & 17 & 89 & 3 & 43 \\
\hline Trimethoprim/Sulfamethoxazole & 13 & 23 & 8 & 42 & 5 & 71 \\
\hline
\end{tabular}

Note: No. of specimens tested by microorganisms: [ ${ }^{*}$ Klebsiella pneumoniae $(\mathrm{n}=56)$ subdivided in: blood $(\mathrm{n}=17)$, urine $(\mathrm{n}=17)$, tracheal aspirate $(\mathrm{n}=12)$, tissue fragment $(n=6)$, abdominal fluid $(n=3)$ and BAL $(n=1)] ;\left[{ }^{* *}\right.$ Serratia marcescens $(n=19)$ subdivided in: blood $(n=8)$, tracheal aspirate $(n=6)$, catheter tip $(n=3)$, abdominal fluid $(\mathrm{n}=1)$ and urine $(\mathrm{n}=1)]$; [*** Enterobacter cloacae $(\mathrm{n}=7)$ subdivided in: tracheal aspirate $(\mathrm{n}=4)$, abdominal fluid $(\mathrm{n}=2)$ and tissue fragment $(\mathrm{n}=1)]$. $(\mathrm{n}=82)$. 


\section{DISCUSSION}

The mean age of the study groups was 71 years, well above the data in the literature, which ranged from 49 to 64 years $^{(16-18)}$. In this case, the high age was mainly attributed to the profile of patients attended at the institution: chronic, with the need for semi-intensive care and who remained hospitalized for a longer time. However, the prevalence of males, marital status, skin color and education did not obtain a specific explanation in the literature regarding infectious events ${ }^{(16,19)}$.

Klebsiella pneumoniae was the most frequent species, mainly in BSI, respiratory tract infections and urinary tract infection. Studies have shown the prevalence of this microorganism in BSI and have highlighted the importance of the etiological agent for the current epidemiological context. Primary bloodstream infections are generally associated with the use of vascular catheters because such devices have direct binding to blood vessels, and such invasiveness can be considered a gateway for microorganisms ${ }^{(18,20)}$.

The presence of enterobacteria in bronchoalveolar lavage samples was also highlighted. A systematic review showed that the lung was the most common infection site related to Klebsiella pneumoniae ${ }^{(21)}$. Another study found similar findings in tracheal secretions ${ }^{(19)}$.

Regarding the outcome of patients, it was highlighted that the high lethality of $62 \%$ observed in this study was similar to other studies which presented rates above $50 \%$. It is inferred that the HAI topography, as well as the limitation to the antimicrobial treatments received during the hospitalization period have a strong impact on the evolution of the patient's death. In addition, aspects related to the complexity of the microorganism, the severity of the patient, as well as their comorbidities influence the high lethality rate ${ }^{(16-18,22)}$.

Enterobacteria carrying the blaKPC gene contribute to spreading the phenomenon of antimicrobial resistance, which has been surpassing continental barriers and becoming a problem which directly affects the current treatments ${ }^{(4,23)}$. Changes in the sensitivity profile of microorganisms have been promoting therapeutic limitations and generating concern about what has been done worldwide to combat resistance $\mathrm{e}^{(5,23)}$.

This study showed that the antimicrobials of the carbapenem group had a very low sensitivity profile, according to the parameters described in Technical Note 01/2013 of ANVISA (Agência Nacional de Vigilância Sanitária - Brazilian Health Regulatory Agency) and the Facility Guidance for Control of Carbapenem-resistant Enterobacteriaceae of the Atlanta $\mathrm{CDC}^{(5,13)}$. A study has reported that the sensitivity profile of microorganisms to antimicrobials can range from $0 \%$ to $4 \%$ when tested on Klebsiella pneumoniae ${ }^{(24)}$. Similar data were also found in the Serratia marcescens and Enterobacter cloacae species ${ }^{(25-26)}$. It is important to emphasize the fact that the therapeutic limitation is a problem due to the rapid dissemination of resistance genes among the community, negatively impacting the outcome of hospitalized patients ${ }^{(24)}$.
There was a low sensitivity of the microorganisms to cefepime, ceftazidime and ceftriaxone in the cephalosporin group. Gentamicin, belonging to the aminoglycoside group, was considered a good therapeutic option, and the sensitivity could vary between $52 \%$ and $79 \%$. Tigecycline also proved to be a good indication for treatment. Colistin was effective in combating Klebsiella pneumoniae (84\%) and Enterobacter cloacae (100\%), but it did not obtain the same sensitivity for Serratia marcescens (5\%). This can be attributed to the already intrinsic resistance of the microorganism to the colistin antimicrobial among the last species ${ }^{(27)}$. However, despite the availability of some drugs for treating HAIs, there is still a restriction for using these options, with the use of combination therapy and/or dose optimization being indicated to decrease mortality ${ }^{(28-29)}$.

In this sense, it is worth emphasizing that the pharmaceutical industries have reduced investments for new discoveries of antibiotics at the present time. The approval of new antimicrobials by the US Food and Drug Administration (FDA) has reduced by $56 \%$ in the last 20 years, warning of the importance of creating measures which encourage and facilitate the development of new substances, especially for the fight against infections caused by resistant microorganisms ${ }^{(30)}$.

This study had some limitations that should be recognized. The data collection occurred retrospectively and therefore problems were noted in the data in the electronic medical records. It was also observed that there were only three microorganism species confirmed for the blaKPC gene, showing that the epidemiological and microbiological profile only represented the reality of the study hospital.

\section{CONCLUSION}

In this study it was possible to reaffirm the importance of Carbapenemase-producing Enterobacteriaceae, in particular carriers of the blaKPC gene for the current epidemiological context. Resistance genes spread rapidly in the hospital setting, and end up negatively impacting the patient's life by limiting the antimicrobial options for treating HAIs due to the more severe complications, which can lead to death.

It is important to conclude that the multidisciplinary team should be more involved in preventing and controlling infections. This will reduce the length of hospital stay, morbidity and mortality, and care costs related to infectious diseases.

The epidemiological profile of HAIs found in this study can be prevented by infection prevention and control programs to reduce infectious diseases caused by enterobacteria which carry the blaKPC gene. It is hoped that the data found in this study may contribute to new research perspectives for HAIs, however new research is still fundamental and imperative to be carried out to enrich and understand this theme. 


\section{RESUMO}

Objetivo: Levantar o perfil epidemiológico das Infecções relacionadas à Assistência à Saúde causadas por Enterobactérias que carreiam o gene Klebsiella pneumoniae Carbapenemase (blaKPC) no ambiente hospitalar. Método: Estudo descritivo, realizado em um hospital privado de Belo Horizonte, MG, Brasil que incluiu todos os pacientes com infecções causadas por Enterobactérias que carreiam o gene Klebsiella pneumoniae Carbapenemase. Os dados foram coletados pelo Sistema Automatizado de Controle de Infecção Hospitalar e analisados por estatística descritiva pelo programa Epi Info 7. Resultados: Participaram do estudo 82 pacientes. A Klebsiella pneumoniae foi a espécie mais frequente $(68 \%)$ isolada no sangue (30\%), lavado broncoalveolar $(22 \%)$ e urina (18\%). Em relação à topografia, prevaleceu a infecção de corrente sanguínea associada a cateter (30\%). Na avaliação do desfecho, destacou-se uma taxa de letalidade de $62 \%$ dos pacientes. Conclusão: os genes de resistência se disseminam de forma rápida, limitando as opções antimicrobianas para o tratamento dos agravos infecciosos. O perfil epidemiológico das Infecções relacionadas à Assistência à Saúde encontrado neste estudo pode ser trabalhado de forma preventiva pelos programas de prevenção e controle de infecção.

\section{DESCRITORES}

Enterobacteriaceae; Infecção Hospitalar; Resistência Microbiana a Medicamentos; Controle de Infecções.

\section{RESUMEN}

Objetivo: Inventariar el perfil epidemiológico de las Infecciones relacionadas con la Asistencia Sanitaria causadas por Enterobacterias que transfieren el gen Klebsiella pneumoniae Carbapenemasa (blaKPC) en el entorno hospitalario. Método: Estudio descriptivo, 1levado a cabo en un hospital de Belo Horizonte, MG, Brasil, que incluyó a todos los pacientes con infecciones causadas por Enterobacterias que transfieren el gen Klebsiella pneumoniae Carbapenemasa. Los datos fueron recogidos por el Sistema Automatizado de Control de Infección Hospitalaria y analizados por estadística descriptiva por el programa Epi Info 7. Resultados: Participaron en el estudio 82 pacientes. La Klebsiella pneumoniae fue la especie más frecuente (68\%) aislada en la sangre (30\%), lavado broncoalveolar (22\%) y orina (18\%). Con relación a la topografía, prevaleció la infección de torrente sanguíneo asociada con catéter (30\%). En la evaluación de los resultados, se destacó una tasa de letalidad del 62\% de los pacientes. Conclusión: Los gentes de resistencia se diseminan de modo rápido, limitando las opciones antimicrobianas para el tratamiento de los agravamientos infecciosos. El perfil epidemiológico de las Infecciones relacionadas con la Asistencia Sanitaria encontrado en este estudio los puede trabajar de manera preventiva los programas de prevención y control de infección.

\section{DESCRIPTORES}

Enterobacteriaceae; Infección Hospitalaria; Farmacorresistencia Microbiana; Control de Infecciones.

\section{REFERENCES}

1. Alvim ALS, Santos FCR. Medidas de precaução de contato para prevenção e controle de infecções: relato de experiência. Rev Enferm Centro Oeste Min [Internet]. 2017 [citado 2018 jan. 7];7:e1333. Disponível em: http://seer.ufsj.edu.br/index.php/recom/article/view/1333/1583

2. Allegranzi B, Bagheri Nejad S, Combescure C, Graafmans W, Attar H, Donaldson L, et al. Burden of endemic health-care-associated infection in developing countries: systematic review and meta-analysis. Lancet. 2011;377(9761):228-41. DOI: http://dx.doi.org/10.1016/ S0140-6736(10)61458-4.

3. Mckibben L, Horan T, Tokars JI, Fowler G, Cardo DM, Pearson ML, et al. Guidance on public reporting of healthcare-associated infections: recommendations of the Healthcare Infection Control Practices Advisory Committee. Am J Infect Control. 2005;33(4):217-26. DOI: http:// dx.doi.org/10.1016/j.ajic.2005.04.001

4. World Health Organization. Antimicrobial resistance global report on surveillance [Internet]. Geneva: WHO; 2014 [cited 2018 Jan 6]. Available from: http://apps.who.int/iris/bitstream/10665/112642/1/9789241564748_eng.pdf

5. Center for Disease Control and Prevention. Facility guidance for control of Carbapenem-resistant Enterobacteriaceae (CRE) [Internet]. Atlanta: CDC; 2015 [cited 2018 Jan 6]. Available from: https://www.cdc.gov/hai/pdfs/cre/cre-guidance-508.pdf

6. Queiroz GM, Silva LM, Pietro RCLR, Salgado HRN. Multirresistência microbiana e opções terapêuticas disponíveis. Rev Bras Clin Med [Internet]. 2012 [citado 2018 jan. 6];10(2):132-8. Disponível em: http://files.bvs.br/upload/S/1679-1010/2012/v10n2/a2783.pdf

7. Papadimitriou-Olivgeris M, Fligou F, Bartzavali C, Zotou A, Spyropoulou A, Koutsileou K, et al. Carbapenemase-producing Klebsiella pneumoniae bloodstream infection in critically ill patients: risk factors and predictors of mortality. Eur J Clin Microbiol Infect Dis. 2017;36(7):1125-31. DOI: http://dx.doi.org/10.1007/s10096-017-2899-6.

8. Munoz-Price LS, Quinn JP. The spread of Klebsiella pneumoniae carbapenemases: a tale of strains, plasmids, and transposons. Clin Infect Dis. 2009;49(11):1739-41. DOI: http://dx.doi.org/10.1086/648078.

9. Abboud CS, Souza EE, Zandonadi EC, Borges LS, Miglioli L, Monaco FC, et al. Carbapenem-resistant Enterobacteriaceae on a cardiac surgery intensive care unit: successful measures for infection control. J Hosp Infect. 2016;94(1):60-4. DOI: http://dx.doi.org/10.1016/j. jhin.2016.06.010

10. Borges FK, Moraes TA, Drebes CVE, Silva ALT, Cassol R, Falci DR. Perfil dos pacientes colonizados por enterobactérias produtoras de KPC em hospital terciário de Porto Alegre, Brasil. Clin Biomed Res [Internet]. 2015 [citado 2018 jan. 7];35(1). Disponível em: http://seer.ufrgs. br/index.php/hcpa/article/view/51134

11. Norcia BMM, Capobiango JD, Vespero EC, Pelisson M. Pacientes pediátricos portadores de enterobactéria resistente aos carbapenêmicos em um hospital escola do Sul do Brasil. J Infect Control [Internet]. 2015 [citado 2018 jan.7];4(1):11-5. Disponível em: http://jic.abih.net. br/index.php/jic/article/view/95/pdf

12. Center for Disease Control and Prevention. Identifying healthcare-associated Infections (HAI) for NHSN surveillance [Internet]. Atlanta: CDC; 2017 [cited 2018 Jan 8]. Available from: https://www.cdc.gov/nhsn/pdfs/pscmanual/2psc_identifyinghais_nhsncurrent.pdf

13. Brasil. Ministério da Saúde; Agência Nacional de Vigilância Sanitária. Nota Técnica n. 01/2013 - Medidas de prevenção e controle de infecções por Enterobactérias multiresistentes [Internet]. Brasília: ANVISA; 2013 [citado 2018 jan. 8]. Disponível em: https://www20. anvisa.gov.br/segurancadopaciente/index.php/alertas/item/nota-tecnica-n-01-2013 
14. Clinical and Laboratory Standards Institute. MO2-A11: performance standards for antimicrobial disk susceptibility tests: approved standard [Internet]. Wayne; 2015 [cited 2018 Jan 6]. Available from: https://clsi.org/media/1631/m02a12_sample.pdf

15. Brasil. Ministério da Saúde. Portaria n. 466, de 12 de dezembro de 2012 [Internet]. Brasília; 2012 [citado 2018 jan. 8]. Disponível em: http://bvsms.saude.gov.br/bvs/saudelegis/cns/2013/res0466_12_12_2012.html

16. Mariappan S, Sekar U, Kamalanathan A. Carbapenemase-producing Enterobacteriaceae: risk factors for infection and impact of resistance on outcomes. Int J Appl Basic Med Res. 2017;7(1):32-9. DOI: http://dx.doi.org/10.4103/2229-516X.198520.

17. Carrilho C, Oliveira LM, Gaudereto J, Perozin JS, Urbano MR, Camargo CH, et al. A prospective study of treatment of carbapenem-resistant Enterobacteriaceae infections and risk factors associated with outcome. BMC Infect Dis [Internet]. 2016 [cite 2018 Jan 8];16:629. Available from: https://www.ncbi.nlm.nih.gov/pmc/articles/PMC5096338/

18. Zarkotou O, Pournaras S, Tselioti P, Dragoumanos V, Pitiriga V, Ranellou K, et al. Predictors of mortality in patients with bloodstream infections caused by KPC-producing Klebsiella pneumoniae and impact of appropriate antimicrobial treatment. Clin Microbiol Infect. 2011;17(12):1798-803. DOl: http://dx.doi.org/10.1111/j.1469-0691.2011.03514.x

19. Seibert G, Meneghetti BH, Righi RA, Forno NLFD, Salla A. Infecções hospitalares por enterobactérias produtoras de Klebsiella pneumoniae carbapenemase em um hospital escola. Einstein [Internet]. 2014 [citado 2018 jan. 8];12(3):282-86. Disponível em: http://www.scielo.br/ pdf/eins/v12n3/pt_1679-4508-eins-12-3-0282

20. Dortet L, Bréchard L, Poirel L, Nordmann P. Rapid detection of carbapenemase-producing Enterobacteriaceae from blood cultures. Clin Microbiol Infect. 2014;20(4):340-44. DOI: http://dx.doi.org/10.1111/1469-0691.12318

21. Tischendorf J, Avila RA, Safdar N. Risk of infection following colonization with carbapenem-resistant Enterobactericeae: a systematic review. Am J Infect Control. 2016;44(5):539-43. DOI: http://dx.doi.org/10.1016/j.ajic.2015.12.005

22. Giacobbe DR, Del Bono V, Trecarichi EM, Rosa FG, Giannella M, Bassetti M, et al. Risk factors for bloodstream infections due to colistin-resistant KPC-producing Klebsiella pneumoniae: results from a multicenter case-control-control study. Clin Microbiol Infect. 2015;21(12):1106.e1-8. DOI: http://dx.doi.org/10.1016/j.cmi.2015.08.001.

23. Blair JMA, Webber MA, Baylay AJ, Ogbolu DO, Piddock LJ. Molecular mechanisms of antibiotic resistance. Nat Rev Microbiol. 2015; 13(1):42-51. DOI: http://dx.doi.org/1038/nrmicro3380

24. Bratu S, Landman D, Haag R, Recco R, Eramo A, Alam M, et al. Rapid spread of carbapenem-resistant Klebsiella pneumoniae in New York City: a new threat to our antibiotic armamentarium. Arch Intern Med. 2005;165(12):1430-35. DOI: http://dx.doi.org/10.1001/ archinte.165.12.1430

25. Rechenchoski DZ, Dambrozio AML, Vivan ACP, Schuroff PA, Burgos TDN, Pelisson M, et al. Antimicrobial activity evaluation and comparison of methods of susceptibility for Klebsiella pneumoniae carbapenemase (KPC)-producing Enterobacter spp. isolates. Braz J Microbiol [Internet]. 2017 [cited 2018 Jan 9];48(3):509-14. Available from: https://www.ncbi.nlm.nih.gov/pmc/articles/PMC5498445/

26. Lee HK, Park YJ, Kim JY, Chang E, Cho SG, Chae HS, et al. Prevalence of decreased susceptibility to carbapenems among Serratia marcescens, Enterobacter cloacae, and Citrobacter freundii and investigation of carbapenemases. Diagn Microbiol Infect Dis. 2005;52(4):331-6. DOI: http://dx.doi.org/10.1016/j.diagmicrobio.2005.04.012

27. Magiorakos AP, Srinivasan A, Carey RB, Carmeli Y, Falagas ME, Giske CG, et al. Multidrug-resistant, extensively drug-resistant and pandrug-resistant bacteria: an internation expert proposal for interim standard definitions for acquired resistance. Clin Microbiol Infect. 2012;18(3):268-81. DOI: http://dx.doi.org/10.1111/j.1469-0691.2011.03570.x

28. Ni W, Han Y, Liu J, Wei C, Zhao J, Cui J, et al. Tigecycline treatment for carbapenem-resistant enterobacteriaceae infections: a systematic review and meta-analysis. Medicine (Baltimore). 2016;95(11):e3126. DOI: http://dx.doi.org/10.1097/MD.0000000000003126

29. Morrill HJ, Pogue JM, Kaye KS, La Plante KL. Treatment options for carbapenem-resistant enterobacteriaceae infections. Open Forum Infect Dis [Internet]. 2015 [cited 2018 Jan 9];2(2):ofv050. Available from: https://www.ncbi.nlm.nih.gov/pmc/articles/PMC4462593/

30. Spellberg B, Powers JH, Brass EP, Miller LG, Edwards JE Jr. Trends in antimicrobial drug development: implications for the future. Clin Infect Dis. 2004;38(9):1279-86. DOl: http://dx.doi.org/10.1086/420937 